\title{
Index of Relative Importance of the Dietary Proportions of Sloth Bear (Melursus ursinus) in Semi-Arid Region
}

\author{
Tana P. MEWADA \\ Wildlife Institute of India, POBox\#18, Chandrabani, Dehradum, Uttarakhand, India; \\ tanamewada@wii.gov.in (*correspondence author)
}

\begin{abstract}
Characterisations of the Sloth bear (Melursus ursinus) diet during three distinguished seasons (monsoon, winter and summer) in the semi-arid region of western India was under study. Diet was estimated using scat analysis, based on the calculation of Index of Relative Importance (IRI) in order to determine the contribution of different food items in the Sloth bear diet. Sloth bears were observed to feed on a wide variety of prey items. They are specialized on insect prey, particularly termites or ants, and are considered as myrmecophagous. The myrmecophagousis character was confirmed by the highest score of insect part (IRI = 21.37) from the samples $(\mathrm{n}=566)$, which was followed by Diospyros melanoxylon (IRI Score 13.51), Ficus spp. (IRI score 12.69) and Cassia fistula (IRI Score 10.13). Sloth bear dietary proportions varied among the three seasons under the study interval. Data suggested that the Sloth bear is essentially behaving as an omnivore, having similar diet (in terms of high incidence of wild fruits and insects) with the bears inhabiting semi-arid regions. The opportunistic and generalist strategy of selecting diet ingredients has probably helped the species to survive in semi-arid habitat across the North Gujarat.
\end{abstract}

Keywords: diet, food habits, generalist forager, insectivorous, omnivore, semi-arid, scat analysis

\section{Introduction}

Scat analysis is increasingly being used to determine the diets of pinnipeds (seals and sea lions), canids (wolves, dogs, coyotes, and foxes), ursids (bears), felids (cats), viverrids (civets and genets) and mustelids (otters and badgers) (Hewitt and Robbins, 1996; Pardini, 1998; Patterson et al., 1998; Ferreras and Macdonald, 1999; Krueger et al., 1999; Virgos et al., 1999; Bull, 2000; Núñez et al., 2000; Bartoszewicz and Zalewski, 2003; Hutchings, 2003; Moleon and Gil-Sainchez, 2003; Silva and Talamoni, 2003; Malo et al., 2004; Mukherjee et al., 2004; Trite and Joy, 2005). Diets of mammals are often inferred by the identification of hard parts from prey eaten and recovered in fecal remains (scats). The frequencies with which particular prey species occur among collections of scats are easily compiled to describe the average diet, and this data can be used to compare diets between different geographic regions, or across years and seasons (Trite and Joy, 2005).

Diet descriptions were commonly made by determining the frequency of occurrence and food items' abundance over a monthly, seasonally or yearly time period. As these measures alone are thought to be insufficient to define the relative importance of each food item in the scat content and therefore for a species' diet, many authors have used compound indices including two or more independent measures. In this regard, Index of
Relative Importance (IRI) is reliable in order to compare the results and to indicate the consumed food in different seasons (Gümüs et al., 2002; Home and Jhala, 2009). Food utilization is an important aspect in the study of carnivore ecology, since trophic resources dominate several aspects of their biology (Macdonald, 1983; Bekoff et al., 1984).

Most bears are opportunistic omnivores and their activities are governed by the food availability and dietary components within their habitat. The nutrition plays an important role also in the reproductive rate of female bears (Jonkel and Cowan, 1971). Most species of bears have been documented to feed on insects, especially ants, at least on occasion (Joshi et al., 1997). However, the Sloth bear is the only member of the Ursidae family having myrmecophagous adaptations to feed on insects, especially termites and ants (Joshi et al., 1997; Laurie and Seidensticker, 1977). Like other bears, but unlike other myrmecophagous mammals, Sloth bear diet vary seasonally and geographically across their range from South Nepal through India and Sri Lanka, depending on the availability of food and hardness of termite mounds (Laurie and Seidensticker, 1977; Baskaran, 1990; Gopal, 1991; Gokula et al., 1995; Baskaran et al., 1997; Joshi et al., 1997, Mewada, 2010). The Sloth bear's insect diet supports diversity in regard to the different forms consumed, such as red ants, termites, beetles and honey bees (Mewada and Dharaiya, 2009). 
282

The main purpose of the current research was to investigate food habits of Sloth bears from North Gujarat, an area highly pressurised by human activities and with fragmented habitat within which Sloth bear distribution is ignored. Information on composition and seasonal variations in bear diet can be collected either through foraging observations or indirectly through scat analysis (Mewada, 2010). Sloth bears in the study area forage primarily during night time, thus it was difficult to collect data based on direct observations, and therefore it depended on scat samples to provide information on food habits of the Sloth bear. The present study examined the diet of the Sloth bear during peculiar three seasons, the monsoon, winter and summer over a period of three years, in semi-arid region.

\section{Materials and Methods}

\section{Study area}

According to the classification of Rodger and Panwar (1988), Gujarat has parts of bio-geographic zones 4B, respectively semi-arid. It can be further classified into subbiotic province 4B3- hilly area of Sabarkantha and Banaskanta composed of dry teak, dry deciduous mixed, Boswellia forests, riverine tracts, dry bamboo brakes and dry scrub forest on the rocky hills (Singh, 2001; Mewada, 2010).

The north Gujarat region studied in the present study harbours two districts: (1) Banaskantha, which lies

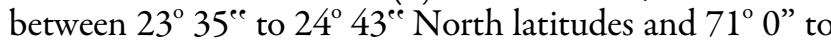
$73^{\circ} 0^{\prime \prime}$ East longitudes on the Banas river. The district is in the North-Western part of Gujarat bordering with Rajasthan. The Sabarkantha district (2) lies between latitudes $23^{\circ} 13^{\prime} 15^{\prime \prime}$ and $24^{\circ} 3530^{\prime \prime}$ North and longitudes $72^{\circ} 47^{\prime \prime} 00^{\prime \prime}$ and $73^{\circ} 37^{\prime \prime} 30^{\prime \prime}$ East on the bank of Sabarmati river. The SK is at the North-East part of the State. The region shares its boundary with the state of Rajasthan and Madhya-Pradesh in the North-East. The topography varies from plains with an elevation gradient of $10 \mathrm{~m}$ to $600 \mathrm{~m}$ above MSL.

The region experiences a high variation in the temperature with the minimum of $5^{\circ} \mathrm{C}$ in the winter and the maximum up to $46^{\circ} \mathrm{C}$ in the summer. Generally, good rains fall once in three years. Rains are quite irregular and temporary drought conditions prevail even during the rainy season. Usually the monsoon season experiences average rainfall of $765 \mathrm{~mm}$, which is providing an ideal environmental condition for the occurrence and abundance of diverse flora and fauna. The climate shows three distinct seasons, as monsoon is lasting, with occasional short breaks, from July to mid September; winter extends from October to February and summer from March to the end of June (Mewada, 2010).

The forest classification by Champion and Seth (1968) supports the study region as part of the Southern Dry Mixed Deciduous forests 4B 3, 4B 4 - (5A/C3) which is further classified into its sub groups $5 / \mathrm{E} 1,5 / \mathrm{E} 1 / \mathrm{DS} 1$, 5/E2, 5/E5, 5/E7 and 5/E9. The forest on hills supports Boswellia and Lannea forest at the top, at the middle are Acacia covered by, while the foot hills are dominated by Anogeissus forests. Apart from these species, the Ambaji Range supports a good density of Bamboo species. The unique ecosystem harbours 483 species of plants including
107 of trees, 58 of shrubs, 219 of herbs, 49 of climbers, 40 of grass and 10 species of lower plants (Pandey, 2004).

The present study area has sparse and scattered forest. The forests erre patchy, fragmented, degraded and surrounded by crop fields and villages with high human and cattle populations.

Survival of Sloth bears depends on availability of suitable habitat. People invade forests and use natural resources, which results in increasing competition and confrontation. Optimum habitat that can support bear population is completely lacking (Mewada, 2010).

\section{Collection of scats}

Scats were collected monthly from the study area, whenever encountered during transect work, tracking of trails of the forests for the bears sings, and surveys of bear dens. Scats were also collected opportunistically from feeding and resting sites, as well as along trails. Scat collection was difficult during the monsoon season because of increased vegetation cover and frequent rains; most scats collected during the monsoon were from den sites.

Scats were sun dried in the field and stored in polythene zip lock bags with wire fold over closures (Custom Poly Packaging, USA) (Bargali et al., 2004, Mewada, 2010). For each scat sample, information regarding date of collection, track and trail identity were recorded.

\section{Estimating food habits}

The scats were analyzed by both qualitative and quantitative analysis. Dietary composition through scat analysis has been widely studied on different bear species. In some studies on Black bear, both scats and stomach contents have been used, while in other cases only scats have been analysed to study the feeding ecology of bears (Schaller, 1967; Laurie and Sedensticker, 1977; Landers et al., 1979; Maehr and Brady, 1984; Mace and Jonkel, 1986; Hamer and Herrero, 1987; Manjrekar, 1989; Baskaran, 1990; Gokula et al., 1995; Joshi et al., 1997; Mewada, 2010). Scat analysis was done as described by many authors (Schaller, 1967; Laurie and Sedensticker, 1977; Landers et al., 1979; Maehr and Brady, 1984; Mace and Jonkel, 1986; Hamer and Herrero, 1987; Manjrekar, 1989; Bhaskaran, 1990; Gokula et al., 1995; Joshi et al., 1997; Bargali, 2002). Scats were weighed separately and each scat sample was washed for further analysis. Each sample was kept in beaker and soaked with water for the volume measures. Following this, scat samples were washed in running water and passed through sieves of the size of $0.7 \mathrm{~mm}$ and $0.4 \mathrm{~mm}$. Remaining portions of the scats were kept in petri dishes for oven drying for 48 hrs at 60 ${ }^{\circ} \mathrm{C}$ and then carefully teased apart using forceps and a needle to separate the indigestible components such as fruit seeds, hairs, scales, feathers, bones and insect chitin.

Seeds were identified by comparing them to known samples and other vegetable matter collected during field surveys. A dissecting microscope was used to identify food items when needed. All inseparable, unidentifiable crushed matter, including parts of insects and fruits, was considered in the unidentified matter.

In the current study, as there was no conversion factor available for computing prey biomass from scats, it was assumed that the proportion of remains of a prey species in the scat gives a fair representation of its proportion in the diet. 
Table 1. Importance of dietary species in the diet of Sloth bear (Melursus ursinus) based on the Index of Relative Importance (IRI)

\begin{tabular}{|c|c|c|c|c|c|}
\hline Species & Frequency \% & IRI & Species & Frequency & IRI \\
\hline Capsicum annum & 0.35 & 0.01 & Triticum vulgare & 0.35 & 0.01 \\
\hline Carrisa congesta & 3.36 & 0.52 & Zea maize & 0.88 & 0.04 \\
\hline Cassia fistula & 14.84 & 10.13 & Ziziphus spp. & 11.31 & 5.88 \\
\hline Cordia dichotoma & 12.54 & 7.24 & Ant & 10.42 & 5.00 \\
\hline Diospyros melanoxylon & 17.14 & 13.51 & Bee wax & 10.60 & 5.17 \\
\hline Ficus spp. & 16.61 & 12.69 & Animal hair & 12.90 & 7.65 \\
\hline Grewia hirsuta & 2.12 & 0.21 & Insect part & 21.55 & 21.38 \\
\hline Madhuca indica & 0.71 & 0.02 & Meat clump & 2.65 & 0.32 \\
\hline Mangifera indica & 0.71 & 0.02 & Un ID material & 23.85 & 26.18 \\
\hline Miliusa tomentosa & 2.83 & 0.37 & Seeds of Cucurbita & 0.35 & 0.01 \\
\hline Phoenix sylvestris & 12.72 & 7.45 & Syzygium cumini & 13.43 & 8.30 \\
\hline
\end{tabular}

Table 2. Food habits of the Sloth bear (Melursus ursinus) in Banaskantha forests, Gujarat, in different seasons

\begin{tabular}{|c|c|c|c|c|}
\hline Dietary species & Monsoon IRI $(\mathrm{n}=228)$ & Winter IRI $(\mathrm{n}=163)$ & Summer IRI $(\mathrm{n}=175)$ & All Scats IRI $(\mathrm{n}=566)$ \\
\hline Capsicum annum & 0.02 & - & - & 0.01 \\
\hline Carrisa congesta & 9.76 & - & 10.24 & 0.52 \\
\hline Cassia fistula & 50.84 & 7.94 & 65.44 & 10.13 \\
\hline Cordia dichotoma & 70.99 & - & 104.06 & 7.24 \\
\hline Diospyros melanoxylon & 316.58 & 0.98 & 15.52 & 13.51 \\
\hline Focus spp. & 150.91 & 6.06 & 47.68 & 12.69 \\
\hline Grewia hirsute & - & 21.90 & - & 0.21 \\
\hline Madhuca indica & - & - & 2.54 & 0.02 \\
\hline Mangifera indica & 2.62 & - & 3.22 & 0.02 \\
\hline Miliusa tomentosa & 4.08 & 3.39 & - & 0.37 \\
\hline Phoenix sylvestris & 113.71 & - & 710.93 & 7.45 \\
\hline Seeds of Cucurbita & 0.03 & - & - & 0.01 \\
\hline Syzygium cumini & 985.59 & - & - & 8.30 \\
\hline Triticum vulgare & 0.02 & - & - & 0.01 \\
\hline Zea maize & 0.02 & 0.46 & - & 0.04 \\
\hline Ziziphus spp. & 17.49 & 363.09 & 5.80 & 5.88 \\
\hline Ant & 11.90 & 61.14 & 5.65 & 5.00 \\
\hline Bee wax & 2.22 & 3.76 & 138.95 & 5.17 \\
\hline Animal hair & 0.73 & 9.74 & 22.54 & 7.65 \\
\hline Insect part & 32.96 & 631.45 & 19.16 & 21.38 \\
\hline Meat clump & - & 0.36 & 7.64 & 0.32 \\
\hline Un ID material & 66.48 & 61.14 & 75.77 & 26.18 \\
\hline
\end{tabular}

It was estimated the minimum number of scats required to give an objective representation of diet composition of Sloth bear by plotting the proportion of items occurred for cumulative increments of ten scats against the total number of scats. The cumulative number of scats at which the proportion of prey categories stabilized indicated the approximate number of scats required to accurately depict the food habits (Jethva and Jhala, 2003; Home and Jhala, 2009).

The Sloth bear diet was estimated by using three different methods based on both frequency and volumetric analysis; viz. Frequency of occurrence (expressed as percentage of the total number of scats), Numerical frequency (expressed as percentage of the total number of occurrences of all food items) (Corbett, 1989; Reynolds and Aebischer, 1991; Paltridge, 2002) and 'Whole scat equivalents' (WSE) which was derived dry volume as percent of prey in scats through quantitatively taken weigh of each separated food item (Angerbjorn et al.,1999; Elmhagen et al., 2000).

In order to minimise the individual biases of the three methods used to estimate the diet of the Sloth bear, Index of

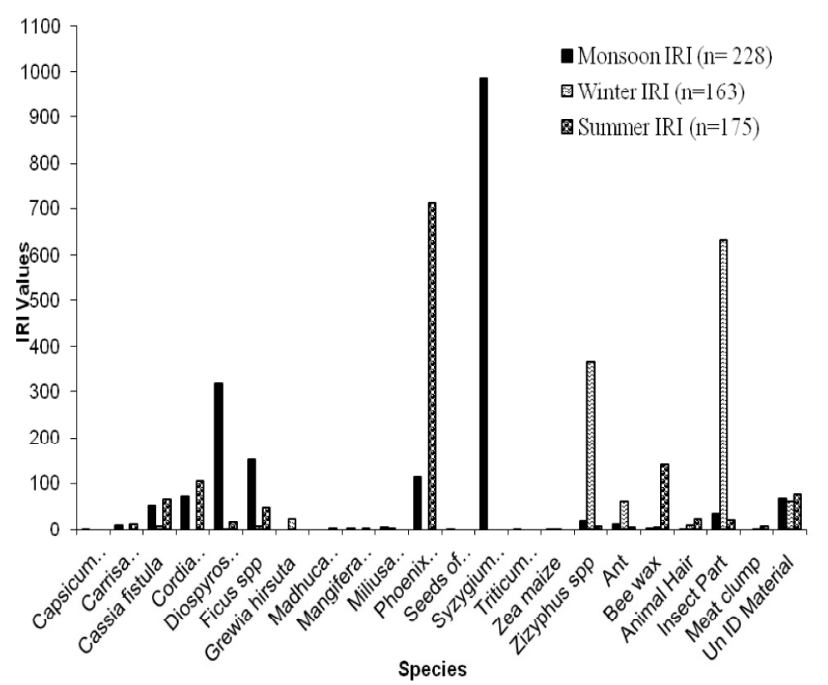

Fig. 1. Differences in the Sloth bear diet among three different seasons; Comparison of IRI scores between monsoon, winter and summer 
Table 3. Season wise food habits of the Sloth bear (Melursus ursinus) in Banaskantha (Gujarat, India) with their IRI

\begin{tabular}{|c|c|c|c|c|c|c|c|c|c|c|c|c|c|c|c|c|}
\hline \multirow[b]{2}{*}{ Species } & \multicolumn{4}{|c|}{ All ScatsData $(\mathrm{n}=566)$} & \multicolumn{4}{|c|}{ Monsoon $(\mathrm{n}=228)$} & \multicolumn{4}{|c|}{ Winter $(n=163)$} & \multicolumn{4}{|c|}{ Summer $(n=175)$} \\
\hline & $\begin{array}{l}\text { Frequency } \\
(\%)\end{array}$ & $\mathrm{NF}$ & WSE & IRI & $\begin{array}{c}\text { Frequency } \\
(\%)\end{array}$ & $\mathrm{NF}$ & WSE & IRI & $\begin{array}{l}\text { Frequency } \\
(\%)\end{array}$ & $\mathrm{NF}$ & WSE & IRI & $\begin{array}{l}\text { Frequency } \\
(\%)\end{array}$ & $\mathrm{NF}$ & WSE & IRI \\
\hline Capsicum anmum & 0.35 & 0.01 & 0.01 & 0.01 & 0.88 & 0.02 & 0.00 & 0.02 & - & - & - & - & - & - & - & - \\
\hline Carrisacongesta & 3.36 & 0.10 & 0.06 & 0.52 & 4.39 & 0.10 & 2.13 & 9.76 & - & - & - & - & 5.14 & 0.13 & 1.86 & 10.24 \\
\hline Cassiafistula & 14.84 & 0.42 & 0.26 & 10.13 & 16.67 & 0.37 & 268 & 50.84 & 6.86 & 0.41 & 0.75 & 7.94 & 19.43 & 0.50 & 2.87 & 65.44 \\
\hline Cordiadichotoma & 1254 & 0.36 & 0.22 & 7.24 & 20.18 & 0.45 & 3.07 & 70.99 & - & - & - & - & 14.29 & 0.37 & 6.91 & 104.06 \\
\hline Diospymsmelanoxylon & 17.14 & 0.49 & 0.30 & 13.51 & 30.70 & 0.69 & 9.63 & 316.58 & 1.71 & 0.10 & 0.47 & 0.98 & 13.71 & 0.35 & 0.78 & 15.52 \\
\hline Ficusspp. & 16.61 & 0.47 & 0.29 & 12.69 & 26.32 & 0.59 & 5.15 & 150.91 & 5.14 & 0.31 & 0.87 & 6.06 & 14.29 & 0.37 & 2.97 & 47.68 \\
\hline Grewiahissuta & 2.12 & 0.06 & 0.04 & 0.21 & - & - & - & - & 6.86 & 0.41 & 278 & 21.90 & - & - & - & - \\
\hline Madhucaindica & 0.71 & 0.02 & 0.01 & 0.02 & - & - & - & - & - & - & - & - & 229 & 0.06 & 1.05 & 2.54 \\
\hline Mangiferaindica & 0.71 & 0.02 & 0.01 & 0.02 & 0.88 & 0.02 & 296 & 2.62 & - & - & - & - & 1.14 & 0.03 & 279 & 3.22 \\
\hline Miliusa tomentosa & 283 & 0.08 & 0.05 & 0.37 & 4.39 & 0.10 & 0.83 & 4.08 & 3.43 & 0.21 & 0.78 & 3.39 & - & - & - & - \\
\hline Phoenixsyluestris & 1272 & 0.36 & 0.22 & 7.45 & 9.65 & 0.22 & 11.57 & 113.71 & - & - & - & - & 28.57 & 0.74 & 24.14 & 710.93 \\
\hline Seed of Cucurbita & 0.35 & 0.01 & 0.01 & 0.01 & 0.88 & 0.02 & 0.01 & 0.03 & - & - & - & - & - & - & - & - \\
\hline Syzygiumaumini & 13.43 & 0.38 & 0.24 & 8.30 & 33.33 & 0.75 & 28.82 & 985.59 & - & - & - & - & - & - & - & - \\
\hline Triticum vulgave & 0.35 & 0.01 & 0.01 & 0.01 & 0.88 & 0.02 & 0.00 & 0.02 & - & - & - & - & - & - & - & - \\
\hline Zeamaize & 0.88 & 0.03 & 0.02 & 0.04 & 0.88 & 0.02 & 0.00 & 0.02 & 1.71 & 0.10 & 0.16 & 0.46 & - & - & - & - \\
\hline Ziziphusspp. & 11.31 & 0.32 & 0.20 & 5.88 & 6.14 & 0.14 & 271 & 17.49 & 22.29 & 1.33 & 14.96 & 363.09 & 6.29 & 0.16 & 0.76 & 5.80 \\
\hline Ant & 10.42 & 0.30 & 0.18 & 5.00 & 11.40 & 0.25 & 0.79 & 11.90 & 1200 & 0.72 & 4.38 & 61.14 & 6.86 & 0.18 & 0.65 & 5.65 \\
\hline Beewax & 10.60 & 0.30 & 0.19 & 5.17 & 5.26 & 0.12 & 0.30 & 2.22 & 3.43 & 0.21 & 0.89 & 3.76 & 24.00 & 0.62 & 5.17 & 138.95 \\
\hline Animal hair & 12.90 & 0.37 & 0.23 & 7.65 & 5.26 & 0.12 & 0.02 & 0.73 & 8.57 & 0.51 & 0.62 & 9.74 & 26.29 & 0.68 & 0.18 & 22.54 \\
\hline Insectpart & 21.55 & 0.61 & 0.38 & 21.38 & 13.16 & 0.29 & 221 & 3296 & 4286 & 2.57 & 12.17 & 631.45 & 9.71 & 0.25 & 1.72 & 19.16 \\
\hline Meatclump & 2.65 & 0.08 & 0.05 & 0.32 & - & - & - & - & 1.71 & 0.10 & 0.11 & 0.36 & 6.86 & 0.18 & 0.94 & 7.64 \\
\hline UnID material & 23.85 & 0.68 & 0.42 & 26.18 & 19.30 & 0.43 & 3.01 & 66.48 & 1200 & 0.72 & 4.38 & 61.14 & 40.00 & 1.04 & 275 & 75.77 \\
\hline
\end{tabular}

Relative Importance (IRI) was calculated (Pinkas et al., 1971; Short et al., 1999; Paltridge, 2002; Medina et al., 2008) to determine the importance of different prey items in the diet [where IRI = (Numerical Frequency + Whole Scat Equivalent) $\times$ Frequency of occurrence]. The IRI scores for different prey items obtained were also separately compared with the diet of three different seasons.

\section{Results}

\section{Diet composition}

Altogether a total of $\mathrm{n}=566$ scats was collected; during the monsoon seasons $n=228$, in winter $n=163$ and in summer $n=175$. There were identified 22 food items including termites, ants, bees, as well as unknown animal matters (bone, hairs and feathers, etc.,) in Sloth bear scats (Table 1). Proportion of occurrences of items for the two principal food categories (insects and fruits) versus cumulative number of scats analysed was stabilized between 193 to 225 scats, suggesting the adequacy of sampling (Estimates, Ver7.5.1).

\section{Year-round diets}

Scat composition was quantified by both frequency of occurrence and percent of dry weight of each food item. In addition to quantifying each item by species, animal matter was grouped into 'insects' and 'other animal matter', while plant matter was categorized into 3 classes: 'crops' (corn and groundnut), 'Ficus' spp. and 'other fruits'.

Insects (IRI score 21.38) contributed as the major proportion of the Sloth bear diet, (both Frequency of occurrence and Numerical frequency), followed by fruits Diospyros melanoxylon (IRI Score 13.51), Ficus spp. (IRI score 12.69) and Cassia fistula (IRI Score 10.13). However, in terms of WSE percent, both insects and fruits comprised $19 \%$ each of the whole scats, followed by arthropods (15\%) and reptiles (13\%) (Table 1). These data indicated that the above are the important dietary composition species for Sloth bear.

The analysis of the Sloth bear scats showed that the bulk of the diet consisted of insect parts (Table 1). IRI scores for S. cumini were significantly different between monsoon and other two seasons (winter and summer), being higher in the monsoon diet (Fig. 1, Table 2). Even so, Phoenix sylvestris showed maximum values within summer samples with the IRI score of 710.93. During winter, the insect (IRI score 631.45) and the Zizyphus spp. (363.09) were reported with the highest scores (Fig. 1, Table 2).

\section{Discussion}

The Sloth bear is essentially an omnivore covering a wide range of food items, signifying its adaptability in the semi-arid habitat of Banaskantha forests, North Gujarat. Insects were the most frequent (IRI score 21.55) prey items in the diet of the Sloth bear, being mostly encountered in the scats analysed. Studies by the Konecny (1987) have indicated that arthropods have a higher proportion of water per unit nitrogen, as well as a higher proportion of fat per gram of body mass, than vertebrates. This may supports the existence of a high proportion of insect in the diet, which would help in harnessing essential nutrients and the required water in such a semi-arid environment. Sloth bear diet studies in the Madumalai Wildlife Sanctuary in Southern India by Baskeran et al. (1997) reported fruit as their major food, irrespective of vegetation types. Ants and termites appeared consistently in the diet.

The percent of occurrence of various diet items varied seasonally. Amongst fruits (vegetative diet) from Sloth bear, IRI score was higher for the Diospyros melanoxylon (13.51) and Ficus spp. (12.69). Consumption of alternative food sources such as fruits, which are associated with low foraging costs, is characteristic of generalist predators (Lucherini et al., 1995; Martinoli et 
al., 2001; Home and Jhala, 2009). Fruits of Ziziphus spp. form an important seasonal resource in Banaskantha forests, with fruiting occurring between November and January showing maximum frequency (22.29\%). Ziziphus spp. (IRI uniform score of 5.88) comprised the bulk of the fruit diet during the winter. High IRI scores of Ziziphus spp. indicated that the Sloth bear actively exploits such sessile seasonal resources, and therefore could be playing an important role in seed dispersal (Herrera, 1989; Home and Jhala, 2009) in this semi-arid region of Banskantha. Availability of ripe fruits varied significantly between seasons and therefore their utilization differ. The fruits of Syzygium cumini, Cassia fistula and Ziziphus spp. formed the dominant component of the Sloth bear diet in Mudumalai Wildlife Sanctuary, Tamilnadu, Southern India. Utilization of plant and animal material differed significantly between seasons. Although the density of fruiting trees varied across vegetation types, the use of fruits did not, except in the thorn forest (Baskeran et al., 1997).

The observations made under study suggested that Sloth bear is a generalist forager, although differing in the proportion of various food items consumed in regard to geographical areas.

Studies on the food habits of Brown bears in Plitvice National Park, Yugoslavia suggested that Brown bears are largely herbivorous and exhibit distinct seasonal cycles in food consumption (Cicnjak et al., 1987). The researchers identified 28 different plants and animal food items and concluded from the scats analysis that plant material consumption varied with phenology. There were also studies on Grizzly bear food habits in the Northern Yukon, Canada (MacHutchon1 and Wellwood, 2003); the conclusion of the study was that in spring the primary food plants were alpine Hedysarum (Hedysarum alpinum) roots and over-wintered berries such as crowberry (Empetrum nigrum), while the main food plants in summer were common horsetail (Equisetum arvense) and bear flower (Boykinia richardsonii). Bears fed primarily on bog blueberries (Vaccinium uliginosum), crowberries, horsetail and bear flower in fall. When blueberries were not available, Grizzly bears dug for alpine hedysarum roots too. Similarly, the seasonal variation in the Sloth bear diet is also reported from the hereby study. Sloth bear of Balaram-Ambaji Wildlife Sanctuary fed on Syzygium cumini (IRI score $=985.59)$ and Diospyros melanoxylon (IRI score $=316.58$ ) fruits in monsoon season. Zizyphus spp. (IRI score $=363.09)$ and Grewia hirsuta (IRI score $=21.90)$ scored high in the winter diet of Sloth bear. Phoenix sylvestris (IRI score = 710.93), bees (IRI score $=138.95$ ) and Cordia dichotoma (IRI score $=104.06)$ were highly consumed during summer. These results strongly inference about the Sloth bear diet in the semi-arid climate and could be stated that its behaviour is of a generalist omnivore.

Availability of fruiting trees, shrubs, termites, ants and water directly influenced the habitat of Sloth bear and their use pattern. Despite myrmecophagous habits (Davidar, 1983; Swenson et al., 1999; Akhtar et al., 2004), Sloth bears are omnivorous and consume large amounts of vegetable matter, particularly fruits (Laurie and Seidensticker, 1977; Gopal, 1991; Gokula, 1991; Gokula and Vardharajan, 1995; Akhtar et al., 2004). Akhtar et al. (2004) documented a total of 30 different food items in scats $(n=1086)$ whereas in the current study 22 food items $(n=566)$ were recorded from Sloth bear scats. Fruits of gular (Ficus racemosa), pakri ( $F$. virens), bargad ( $F$. benghalensis), peepal ( $F$. religiosa), ber (Ziziphus mauritiana), bel (Aegle marmelos), jamun (Syzygium cumini) and mahua (Madhuca indica), in addition to termites (Odontotermes obesus) and ants were the major food items for Sloth bears diet. Yoganand $e t$ al. (2005) conducted a study at the Panna National Park in central India and observed that fruits contributed $56 \%$, ants $29 \%$ and termites $10 \%$ to the annual diet, in terms of ingested biomass, of Sloth bear. Among fruits, Diospyros melanoxylon was the highest contributor, followed by $Z$. mauritiana, while among insects Camponotus spp. ants made the greatest contribution to the diet, followed by Dorylus labiatus. Termites also contributed with a smaller portion (about $10 \%$ to $25 \%$ ) throughout the year. Fruits and ants complemented each other and constituted $70 \%$ to $95 \%$ of the diet respectively. These indicated that fruits are playing an important role in the diet of Sloth bear (e.g. $D$. melanoxylon, Z. mauritiana and C. fistula). A similar study was conducted by Bargali et al. (2004) who analysed Sloth bear 568 scats (Chhattisgarh) and came around 21 species including plants, termites, ants, bees and some of the unidentified animal matter (bone, hairs and tissue).

In the current study, year-round frequencies of occurrence of animal and plant matter were similar. Animal matter constituted $87 \%$ of scats during monsoon and $82 \%$ during winter seasons, but dropped to $65 \%$ during summer. Frequency of occurrence of insects was high during monsoon $(87 \%)$ and winter $(82 \%)$, whereas Ficus species were more common (68\%) during summer season, thus Ficus species were always high in percent weight wise in all seasons.

\section{Management implications}

Several human activities, such as hunting, logging, animal husbandry, collection of non timber forest products (NTFP), agricultural expansion, transport and tourisms, as well as development projects operating around the study area and in some reserve forests, are adversely affecting the bears' habitat and movement. Stakeholder involvement in various aspects of wildlife management can arise many benefits. The specific conservation recommendations for minimizing bear-human conflicts and bear habitat conservation are as follows:

1. As the study revealed, Sloth bears were absent in large expanses of the forest patches of the study area, as the range in the lowlands was hugely fragmented. The entire study area requires a long term scientific study by radio telemetry technique with special emphasis on bear movement and ranging patterns. This can be helpful to know the actual habitat type used by Sloth bears, their home ranges and the important corridors of their movement, which can be further managed through habitat improvement programme for conservation. 
286

2. Every so often resurvey the study area to monitor changes in bear population status, habitat types and resource utilization. Standardized transects to measure Sloth bear diggings for termites can be used to link areas and to consider changes in abundance over time. Moreover, involving local people in collecting information may be helpful in verifying the presence or absence (especially the recent disappearance) of bears in the area.

3. Community forestry development projects can be initiated at a large scale for restoration of degraded lowland forests in study area. Degraded and non-forested area, as well as forest area, are all heavily used by local people; thus, it is necessary to involve the local community in forestry programs, wherein the population learn the value of planting and protecting trees, they could be explained about the expand habitat for Sloth bears and therefore reduce the bear-human interactions. For the development of community and reserve forests, plant species like gular (Ficus racemosa), pakri (F. virens), bargad ( $F$. benghalensis), peepal ( $F$. religiosa $)$, ber (Ziziphus mauritiana), bel (Aegle marmelos), jamun (Syzygium cumini), timbru (Diospyros melanoxylon) and mahua (Madhuca indica) are recommended to be considered for plantation and proper care, as required for the survival of these species in the forest area.

4. The study revealed that the majority of local people are primitive tribes, still attached with their ancient culture. Education should be provided not only for the necessity of protecting forest habitats in order to ensure the survival of Sloth bear, but also for highlighting peoples' benefits from protecting and managing valuable resources. Conservation education should be developed around the theme of maintaining large forest ecosystems that protects many species and simultaneously provide benefits to local people. There is a need to work on the awareness about bear ecology, towards the perception of local community.

5. Apart from the consciousness and participation of local people, the managerial reforms are also required for effective conservation of bears and habitat. It is suggested that more field staff, well prepared and equipped should be employed in such known conflict areas with high bear population.

\section{Conclusions}

This is essentially the first intensive study on the diet of the Sloth bear in a semi-arid landscape of BalaramAmbaji Wildlife Sanctuary, Banaskantha district of North Gujarat, India. The data obtained provide detailed investigation of food habits structure for Sloth bears in the semi-arid region. The dietary spectrum can also be compared to the Sloth bears from similar semi-arid landscapes where insects and seasonal fruits may contribute significantly in terms of preferred diet (Laurie and Seidensticker, 1977; Gopal, 1991; Gokula, 1991; Gokula and Vardharajan, 1995; Akhtar et al., 2004; Bargali et al., 2004; Yoganand et al., 2005, Mewada and Dharaiya, 2010; Mewada, 2010). In a semi-arid landscape like Banaskantha districts of North Gujarat, where resource fluctuations would largely be regulating predator populations and subsequently their dietary spectrum, an opportunistic strategy would definitely favour the species. Thus, being a generalist prowler subsisting on many dietary groups or variety, the Sloth bear has been able to exploit a wider niche, as well as to survive in varied habitats.

\section{Acknowledgements}

Author is thankful to the Chief Wildlife Warden, Gujarat for encouraging the research. All the staffs from Balaram-Ambaji Wildlife Sanctuary are duly acknowledged for their support during the field work and helping with collecting the data.

\section{References}

Akhtar N, Bargali HS, Chauhan NPS (2004). Sloth bear habitat use in disturbed and unprotected areas of Madhya Pradesh, India. Ursus 15(2):203-211.

Angerbjorn A, Tannerfeldt M, Erlinge S (1999). Predator prey relationships: arctic foxes and lemmings. Journal of Animal Ecology 68:34-49.

Gümüs A, Yilmaz M, Polat N (2002). Relative importance of food items in feeding of Chondrostoma regium (Heckel, 1843), and its relation with the time of annulus formation. Turkish Journal of Zoology 26(3):271-278.

Bargali HS, Akhtar N, Chauhan NPS (2004). Feeding ecology of Sloth bears in a disturbed area in central India. Ursus 15(2):212217.

Bargali HS (2002). Ecology of problematic Sloth bear (Melursus ursinus) and mitigation of Human-Bear conflicts in north Bilaspur forest division, Madhya Pradesh. PhD thesis, The Saurashtra University, Rajkot, India.

Bartoszewicz M, Zalewski A (2003). American mink, Mustela vison diet and predation on waterfowl in the Slonsk Reserve, western Poland. Folia Zoologica 52:225-238.

Baskaran N (1990). An ecological investigation on the dietary composition and habitat utilization of Sloth bear (Melursus ursinus) at Mudumalai wildlife sanctuary, Tamil Nadu (South India). Thesis, AVC College, Mannambandal, Tamil Nadu, India.

Baskaran N, Sivaganesan N, Krishnamoorthy J (1997). Food habits of the Sloth bear in Mudumalai Wildlife Sanctuary, Tamil Nadu, Southern India. Journal of Bombay Natural History Society 94(1):1-9.

Bekoff M, Daniels TJ, Gittleman JL (1984). Life history patterns and comparative social ecology of carnivores. Annual Review of Ecology and Systematics, pp 191-232.

Bull EL (2000). Seasonal and sexual differences in American marten diet in north-eastern Oregon. Northwest Science 74:186-191.

Champion SH, Seth SK (1968). A revised survey of forest types of India, Government of India.

Cicnjak L, Huber D, Roth HU, Ruff RL, Vinovrski Z (1987). Food habits of brown bears in Plitvice lakes national park, Yugoslavia. International Conference on Bear Research and Management 7, Bears: Their Biology and Management pp 221-226. 
Corbett LK (1989). Assessing the diet of dingoes from feces: a comparison of 3 methods. Journal of Wildlife Management 53(2):343-346.

Davidar ERC (1983). Sloth bear's (Melursus ursinus) method of hunting for termite nests. Journal of Bombay Natural History Society 80:637.

Desai AA, Bhaskaran N, Venkatesh S (1997). Behavioural ecology of the Sloth bear in Mudumalai Wildlife Sanctuary and National Park, Tamil Nadu. Report. Bombay Natural History Society, Bombay, India, and Tamil Nadu Forest Department, Chennai, India.

Elmhagen B, Tannerfeldt M, Verucci P, AngerbjoErn A (2000). The arctic fox (Alopex lagopus): an opportunistic specialist. Journal of Zoology 251(2):139-149.

Ferreras P, Macdonald DW (1999). The impact of American mink Mustela vison on water birds in the upper Thames. Journal of Applied Ecology 36(5):701-708.

FSI (2003). Status of the forest report: 2003. Forest Survey of India, Dehradun pp 56-57.

FSI (2005). Status of the forest report: 2005. Forest Survey of India, Dehradun pp 71-74.

Gokula V, Vardharajan M (1995). Food habits of Sloth bear (Melursus ursinus) on Mundanthurai Plateau, Tamil Nadu, India. Tiger Paper 22(4):27-28.

Gokula V (1991). Some aspects on the feeding habits of the Sloth bear (Melursus ursinus) at Mundanthurai Wildlife Sanctuary, Tamilnadu (South India). Thesis, AVC College, Mannambandal Tamil Nadu, India.

Gokula V, Sivaganesan N, Varadarajan M (1995). Food of the Sloth bear (Melursus ursinus) in Mundanthurai Plateau, Tamil Nadu. Journal of Bombay Natural History Society 92:408-410.

Gopal R (1991). Ethological observations on the Sloth bear (Melursus ursinus). Indian Forester 117910):915-920.

Hamer D, Herrero S (1987). Grizzly bear food and habitat in the Front ranges of Banff National Park, Alberta. International Conference on Bear Research and Management 7, Bears: their biology and management pp 199-213.

Herrera CM (1989). Frugivory and seed dispersal by carnivorous mammals, and associated food characteristics, in undisturbed Mediterranean habitats. Oikos 55:250-262.

Hewittr DG, Robbins CT (1996). Estimating grizzly bear food habits from fecal analysis. Wildlife Society Bulletin 24:547-550.

Home C, Jhala YV (2009). Food habits of the Indian fox (Vulpes bengalensis) in Kutch, Gujarat, India. Mammalian Biology 74:403-411.

Hutchings $S$ (2003). The diet of feral house cats (Felis catus) at a regional rubbish tip, Victoria. Wildlife Research 30:103-110.

Jonkel CJ (1971). The black bears in the spruce-fir forest. Wildlife Monograph pp 3-57.

Joshi AR, Garshelis DL, Smith JLD (1997). Seasonal and habitat-related diets of Sloth bears in Nepal. Journal of Mammalogy 78:584-597.

Joshi AR, Garshelis DL, Smith JLD (1995). Home ranges of Sloth bears in Nepal: implications for conservation.
Journal of Wildlife Management 59:204-214.

Konecny MJ (1987). Food habits and energetics of feral house cats in the Galapagos Islands. Oikos 50:24-32.

Krueger S, Lawes M, Maddock A (1999). Diet choice and capture success of wild dog (Lycaon pictus) in HluhluweUmfolozi Park, South Africa. Journal of Zoology 248:543551.

Landers JL, Hamilton RJ, Johnson AS, Marchinton RL (1979). Food habits of black bears in Southern North Carolina. Journal of Wildlife Management 43:143-153.

Laurie A, Seidensticker J (1977). Behavioural ecology of the Sloth bears (Melursus ursinus). Journal of Zoology 182:187-204.

Macdonald DW (1983). The ecology of carnivore social behaviour. Nature 301:379-384.

Mace RD, Jonkel CJ (1986). Local food habits of Grizzly bear in Montana. International Conference on Bear Research and Management 6, Bears: Their Biology and Management pp 105-110.

MacHutchon GA, Wellwood DW (2003) Grizzly bear food habits in the northern Yukon, Canada. Ursus 14(2):225235.

Maehr DS, Brady JR (1984). Food habits of Florida black bears. Journal of Wildlife Management 48:230-235.

Malo A, Lozano J, Huertas D, Virgos E (2004). A change of diet from rodents to rabbits (Oryctolagus cuniculus). Is the wildcat (Felis sil'estris) a specialist predator'? Journal of Zoology 263:401-407.

Manjrekar M (1989). Feeding ecology of black bear (Selenarctos thibetanus Cuvier) in Dachigam National Park, Kashmir. MSc Thesis, Wildlife Institute of India, Dehradun, India.

Medina FM, López-Darias M, Nogales M, Garcia R (2008). Food habits of feral cats (Felis sylvestriscatus $\mathrm{L}$ ) in insular semiarid environments (Fuerteventura, Canary Islands). Wildlife Research 35(2):162-169.

Mewada T (2010). Ecological studies on Sloth bear (Melursus ursinus) with special reference to human-bear conflicts in selected Sloth bear habitats of North Gujarat. PhD Thesis, HNG University, Patan, North Gujarat, India.

Mewada T, Dharaiya N (2010). Seasonal dietary composition of Sloth bear (Melursus ursinus) in the reserve forest of Vijaynagar, North Gujarat, India. TigerPaper 37(2):8-13.

Moleon M, Gil-Sanchez J (2003). Food habits of the wildcat (Felis silvestris) in a peculiar habitat: the Mediterranean high mountain. Journal of Zoology 260:17-22.

Mukherjee S, Goyal SP, Johnsingh AJT, Pitman MRPL (2004). The importance of rodents in the diet of jungle cat (Felis chaus), caracal (Caracal caracal) and golden jackal (Canis aureus) in Sariska Tiger Reserve, Rajasthan, India. Journal of Zoology 262:405-411.

Núñez R, Miller B, Lindzey F (2000). Food habits of jaguars and pumas in Jalisco, Mexico. Journal of Zoology 252: 373379. 
288

Paltridge R (2002). The diets of cats, foxes and dingoes in relation to prey availability in the Tanami Desert, Northern Territory. Wildlife Research 29(4):389-403.

Pandey CN (2004). Gujarat's wild destinations. Gujarat Ecological Education and Research Foundation, Gandhinagar, India.

Pardini R (1998). Feeding ecology of the neo-tropical river otter Lontra longicaudis in an Atlantic forest stream, southeastern Brazil. Journal of Zoology 245:385-391.

Patterson BR, Benjamin LK, Messier F (1998). Prey switching and feeding habits of eastern coyotes in relation to snowshoe hare and white-tailed deer densities. Canadian Journal of Zoology 76:1885-1897.

Pinkas L, Oliphant MS, Iverson ILK (1971). Food habits of Albacore, Blue fin Tuna and Bonito in California waters. California Department of Fish and Game: Fish Bulletin 152: 1-83.

Reynolds JC, Aebischer NJ (1991). Comparison and quantification of carnivore diet by faecal analysis: a critique, with recommendations, based on a study of the red fox Vulpes vulpes. M ammal Review 21(3):97-122.

Rodgers WA, Panwar HS (1988). Planning wildlife protected area network in India, Vol 1. The Report. Wildlife Institute of India, Dehradun.

Schaller GB (1967). The deer and the tiger: a study of wildlife in India. University of Chicago Press, Chicago.
Short J, Calver MC, Risbey DA (1999). The impact of cats and foxes on the small vertebrate fauna of Heirisson Prong, Western Australia; exploring potential impact using diet analysis. Wildlife Research 26 (5):621-630.

Silva JA, Talamoni SA (2003). Diet adjustments of maned wolves, Chrysocyon brach/yurus (Illliger) (Mammalia, Canidae), subjected to supplemental feeding in a private natural reserve, southeastern Brazil. Revista Brasileira de Zoologia 20:339-345.

Singh HS (2001). Natural heritage of Gujarat. Gujarat Ecological Education and Research Foundation, Gandhinagar, India.

Swenson EA, Janssonr E, Riig R, Sandegren F (1999). Bears and ants: myrmecophagy by brown bears in central Scandinavia. Canadian Journal of Zoology 77:551-561.

Trites AW, Joy R (2005). Dietary analysis from fecal samples: how many scats are enough? Journal of Mammalogy 86(4):704-712.

Virgos E, Llorente M, Cortés Y (1999). Geographical variation in genet (Genetta genetta L.) diet: a literature review. Mammal Review 29(2):117-126.

Yoganand K, Rice CG, Johnsingh AJT (2005). Evaluating Panna National Park with special reference to ecology of Sloth bear (Melursus ursinus). Final Project Report, Submitted to Wildlife Institute of India, Dehradun, Uttrakhand, India. 